\title{
A Socio-Institutional Approach to Brighten Complexity under Agricultural Pest Invasion Conditions
}

\author{
David Romero Manrique de Lara ${ }^{1}$, Serafin Corral ${ }^{1, *}$, David Legna de la Nuez ${ }^{1}$ and \\ Jesús Hernández Hernández ${ }^{2}$ \\ 1 Departamento de Economía Aplicada y Métodos Cuantitativos, Facultad de Economía, Empresa y Turismo, \\ Universidad de La Laguna (ULL), Campus de Guajara, 38200 La Laguna, Spain; \\ david.r.manrique@gmail.com (D.R.M.d.L.); davidsinfronteras@gmail.com (D.L.d.1.N.) \\ 2 Departamento de Geografía, Facultad de Geografía e Historia, Universidad de La Laguna (ULL), \\ Campus de Guajara, 38200 La Laguna, Spain; jfhdez@ull.es \\ * Correspondence: scorral@ull.edu.es; Tel.: +34-922-317009
}

Academic Editor: Iain Gordon

Received: 28 February 2016; Accepted: 20 June 2016; Published: 25 June 2016

\begin{abstract}
This study illustrates the inherent complexity and uncertainties surrounding the Guatemalan potato moth pest on Tenerife that has affected potato crops for several decades using a Socio-Institutional methodology and a farmers' focus group. It focuses on detecting major socioeconomic and environmental impacts caused by the pest. It identifies the stakeholders and historical decisions involved as well as systemic uncertainties. This methodology generates socially robust knowledge and introduces new variables into future decision-making processes. The results show that the efforts made so far to control the pest, based on technical and scientific knowledge, have not been commensurate with the enormous complexity of the issue. Novel alternatives to eliminate the plague and new recommendations have emerged after the application of the methodology. These alternatives and recommendations are related to breaking the reproduction cycle of the moth; promoting agro-ecological strategies and participatory processes; and dealing with uncertainties such as climate change or loss of agro-biodiversity on the island.
\end{abstract}

Keywords: complexity; socio-institutional analysis; stakeholders; governance; Guatemalan potato moth; uncertainty; agricultural pest

\section{Introduction}

This paper aims to illustrate the complexity involved in dealing with an agricultural pest and the possibilities that exist to establish a more participatory and collaborative practice in pest management and decision-making processes, specifically, regarding the introduction of the Guatemalan potato moth (Tecia solanivora) on the island of Tenerife (Canary Islands). To this end, a Socio Institutional Analysis [1,2] was carried out in order to: (a) identify the stakeholders and their perceptions of the issue; (b) elaborate a broad framing of the problematique; (c) highlight the uncertainties affecting potato production; and (d) elicit new actions and alternatives to take. The approach consisted of an extensive literature review and a series of interviews aimed at broadening the scale of analysis. This provides social, economic and ecological variables that can help experts take relevant decisions in concrete cases where previous management strategies have not achieved the expected results. This information was complemented with farmers' views to enrich the analysis by integrating existing knowledge with their perceptions.

In recent decades, agricultural research and practice, and Integrated Pest Management strategies, have widened its scope to include the study of agricultural systems, taking into account the various 
elements of complexity and paving the way for an agroecological approach [3] in which social-economic and cultural dimensions have gained greater attention [4,5].

Decision-making processes are determined by the behaviour and decisions of the stakeholders involved in them, thus, the analysis of stakeholders' perceptions and concerns is essential to establish a broad framework and support strategic decisions on a particular matter of study. There are several examples in literature about the involvement of stakeholders in environmental and agricultural issues [6,7] showing that more inclusive approaches promote more effective and robust decision making.

According to several authors $[8,9]$ the Guatemalan potato moth (Tecia solanivora) is considered one of the most harmful insect pests of potato crops in Central America, Venezuela, Colombia, Ecuador and the Canary Islands (EU). Controlling this pest has proven to be very difficult due to the healthy appearance of the potatoes during the first stages of infestation, therefore infested potatoes usually evade any kind of phytosanitary control [10] Currently, no specific control methods are available to farmers [9], and this has enabled the moth to spread across Latin America year after year, reaching the Macaronesian region, more specifically the Island of Tenerife. There is, therefore, a clear risk that in the future the moth will make the leap to the European mainland (during the development of this project the presence of Tecia solanivora was reported for the first time in mainland Spain [11,12].

It is a clear example of a conflicting situation in the agricultural sector due to the existing controversy between technicians and farmers on how each of them visualise and face the issue, basically there are discrepancies in the way scientific, social and institutional dimensions interact to ultimately evolve into a policy issue with implications for pest control planning and management. There has been a lack of properly participatory decision-making processes with the different stakeholders who interact in the crop production dynamic. For this reason, this study does not focus solely on the pest itself, but also on all interrelationships surrounding the cultivation of potatoes, since they ultimately facilitate the spread of the pest. In all cases, according to [13], the appearance of T. solanivora in new geographical areas was attributed to the movement of infested tubers and has resulted in population explosions that have significantly harmed potato production, often devastating potato crops in the invaded areas $[14,15]$. This paper broadens the scope of the analyses carried out since the beginning of the problem on the island of Tenerife, which have mainly focused on specific pest controls and have ignored all the associated socioeconomic and environmental complexity.

Therefore, the main aim of this study is to increase awareness of all aspects related to potato growing applying a Socio-Institutional Analysis (SIA) approach in order to facilitate decision-making on the Guatemalan potato moth problem in an island territory. SIA is an effective framework to complement existing scientific knowledge with stakeholders' perceptions and institutional constraints.

Socio-institutional analysis (SIA) frameworks aim at framing complex issues, as well as identifying the stakeholders involved [16]. SIA should be considered as an exploratory process to analyse different structures and social relationships [2]. It provides an accurate approximation of the prevailing social and institutional arrangements, understood as the social context shaped by institutions that define citizens' rights and obligations $[17,18]$. Theoretical aspects of SIA either justifying the necessity of these approaches $[19,20]$ or suggesting guidelines [21] or frameworks of analysis $[22,23]$ have been discussed in the literature. This approach has been used for several proposals, for instance, to introduce governance processes into natural resources management and planning [24,25], to evaluate the risk perception on earthquake hazards [26], or to analyse policy recommendations in agricultural land transfer processes [27].

This socially robust knowledge, as defined by [28], is necessary to understand the complexity of the case, and helps define appropriate alternatives to tackle the problem. In fact, the research carried out into the Guatemalan potato moth in the Canary Islands has produced a valuable contribution to existing knowledge.

This paper is structured as follows. Section 2 describes the importance of potato production in Tenerife, and how the pest has spread throughout the island and its impacts on the local economy, 
employment, landscape, ecology and biodiversity. Section 3 refers to the method used. In Section 4, several results are presented: a stakeholder analysis and mapping; the main deficiencies or wrong decisions taken so far; the hidden uncertainties influencing the problem; and a set of novel alternatives and actions that could be taken in advance by stakeholders. In Section 5, some implications and conclusions are provided.

\section{Case Study}

Potatoes growing on the island of Tenerife, in the Canary Islands, have an undeniable economic, social, cultural, scenic, historical and environmental significance $[29,30]$. Potatoes are grown mainly at an altitude of between 500 and 1000 metres above sea level in the north of the island. However, they are also grown in the south of the island, and below 1000 metres all over the island.

These crops are linked to some cultural traditions of the island, i.e., gastronomy or particular farming practices, and account for approximately $13 \%$ of all cultivated land surface on the island; in terms of production, over 30,000 tons are grown a year. In 2010, it was estimated that potato production in the province of Santa Cruz de Tenerife generated over 13 million euros a year. It is also an important factor in landscape conservation. In addition, potato consumption in the Canary Islands is high (143 g/person/day), as it is one of the staples of the islanders' diet [30].

Ancient potato varieties are grown in the Canary Islands with names such as antigua, de color or bonita. These resemble varieties from Peru, of which they are direct descendants. They are most likely selections, hybrids or variants of those early tubers that were brought to the Islands from America and have contributed to a biodiversity that is unique in the world [31,32].

In 1999, the presence of a moth, unlike local species, was detected in a specific area of the north of the island of Tenerife. In 2000, it was confirmed to be Scrobipalpopsis (Tecia) solanivora, otherwise known as "the Guatemalan potato moth" [32]. This pest has spread over almost all the island mainly by winds and by exchange of infested seeds among farmers, and it has not been possible to contain (see Figure 1).

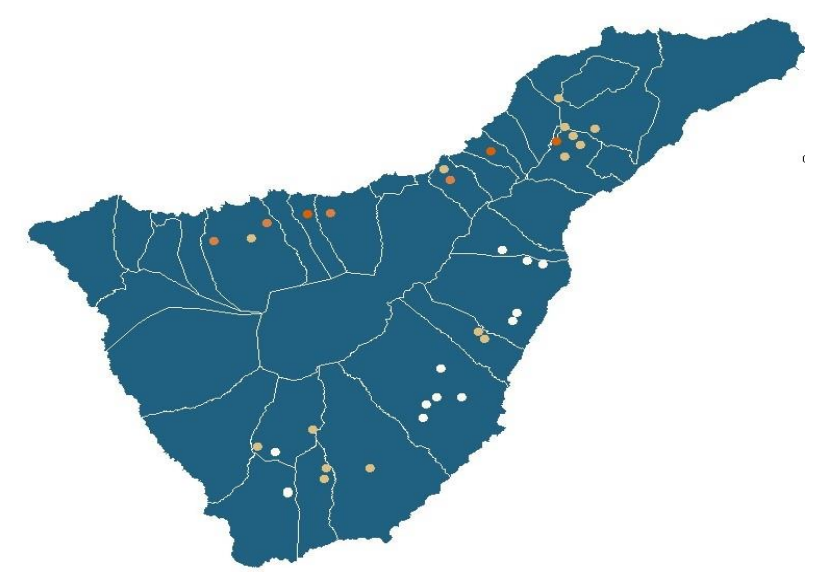

Figure 1. Territorial distribution of the Guatemalan potato moth on the island of Tenerife and the average weekly number caught using the "pheromone trap" system. Source: Servicio Técnico de Agricultura y Desarrollo Rural [33].

Serious infestations of Tecia solanivora have been reported in the Canary Islands, leading to an estimated $25 \%$ decrease in potato production in the archipelago [34]. As a result, there has been a drastic decrease in the area of cultivated land (Figure 2), as well as a significant decline in annual production (Figures 3 and 4 ).

The large number of infested potatoes also has a significant environmental impact on the island's ecosystem, Table 1 summarises these impacts and Table 2 exposes the decisions taken by different stakeholders in order to deal with them. 


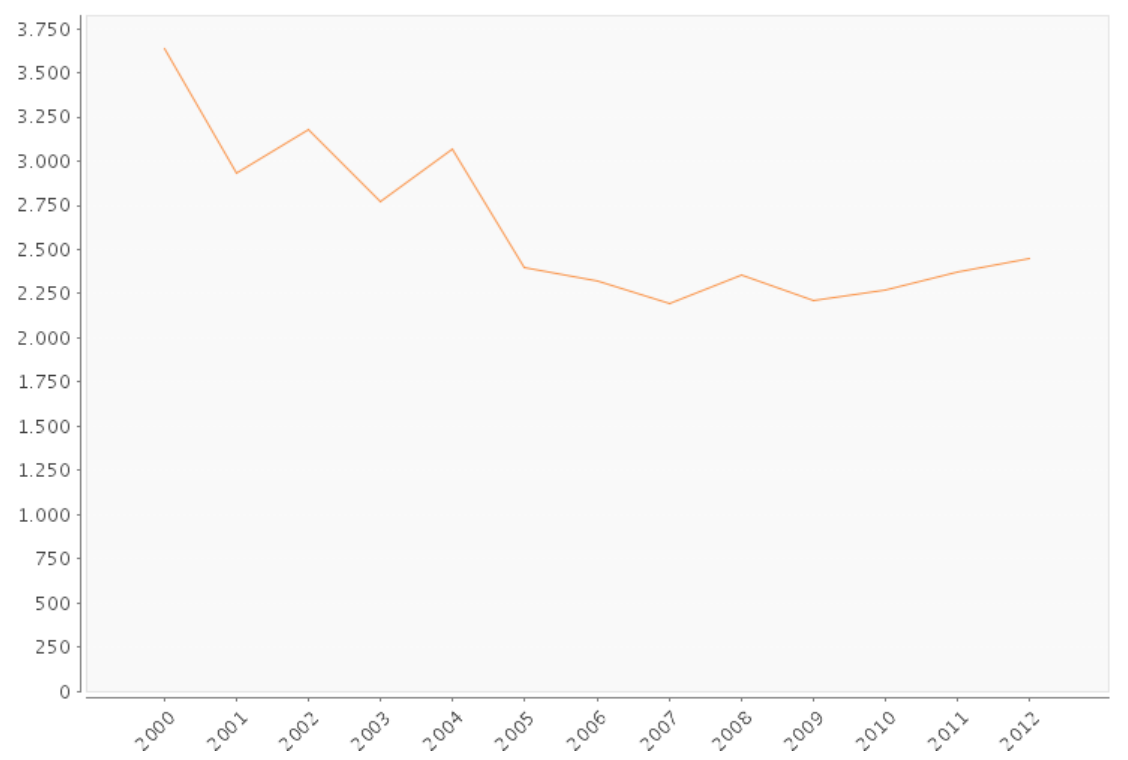

Figure 2. Loss of potato cultivated area (ha) 2000-2012. Source: ISTAC [35].

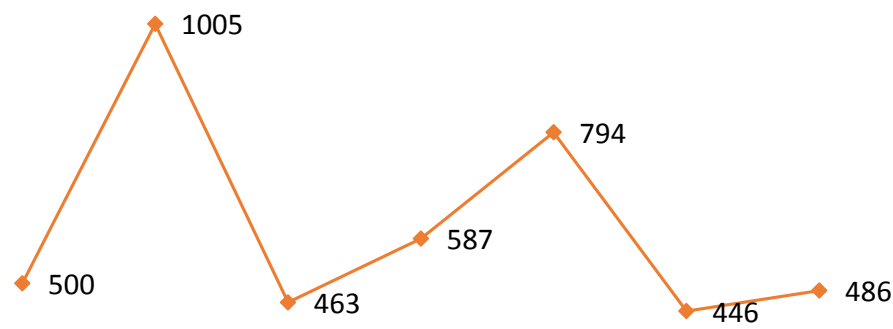

$\begin{array}{lllllll}2004 & 2005 & 2006 & 2007 & 2008 & 2009 & 2010\end{array}$

Figure 3. Tons of infested potatoes (Unit: Tn) (2004-2010). Source: Ríos Mesa [23].

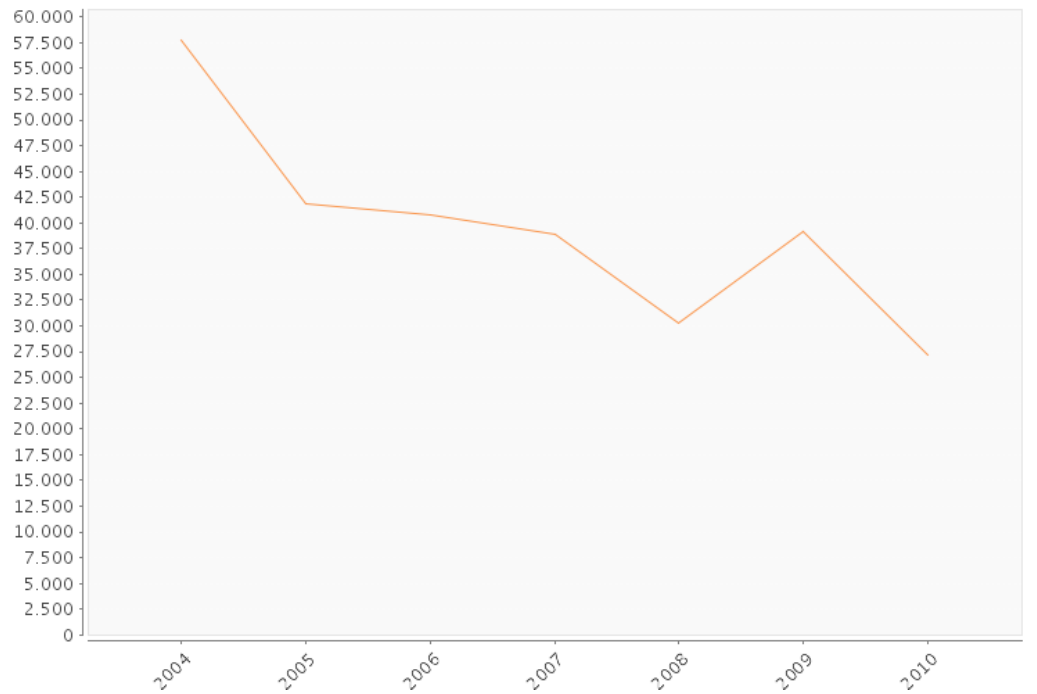

Figure 4. Decline in potato production (Unit: Tn) (2004-2010). Source: ISTAC [25]. 
Table 1. Dimensions, issues and major impacts.

\begin{tabular}{|c|c|c|}
\hline Dimension & Issue & Impact \\
\hline Governance/Institu & Conflicts and disorganization. & Disagreement and low control on the methods to be used (see Section 4.1) \\
\hline \multirow{3}{*}{ Economic } & Exports & $\begin{array}{l}\text { Prohibited by law. } \\
\text { Opportunity cost }\end{array}$ \\
\hline & Economic losses & Average of $300.000 € /$ year. Estimated cost $500 € /$ ton (see Figure 3) \\
\hline & Production decline & See Figure 4 \\
\hline \multirow[t]{2}{*}{ Social } & Employment & $\begin{array}{l}\text { Loss of employment related to potato farming: } \\
\text { Year 2000: } 2366 \text { potato farmers registered. } \\
\text { Year 2005: } 1558 \text { farmers registered. } \\
\text { Year 2010: } 1474 \text { farmers registered. } \\
\text { Source: Gobierno de Canarias, Consejería de Agricultura, Ganadería, Pesca y Aguas [36]. }\end{array}$ \\
\hline & Loss of traditional farming knowledge & No generational replacement. \\
\hline \multirow{2}{*}{ Environmental } & Biodiversity & Risk of loss of genetic varieties of potato. \\
\hline & Farmland abandonment and Landscape transformation & $\begin{array}{l}\text { Agricultural surface has been reduced and land use has changed to inactivity, this } \\
\text { situation affects the value of agricultural landscape on the island. } \\
\text { For instance, } 1096 \text { ha were abandoned during the year } 2008 \text {. } \\
\text { Causes for abandonment are the low profitability of local production, due to the rivalry } \\
\text { with importers and drought periods, which increase pest incidence. }\end{array}$ \\
\hline
\end{tabular}


Table 2. Decisions taken.

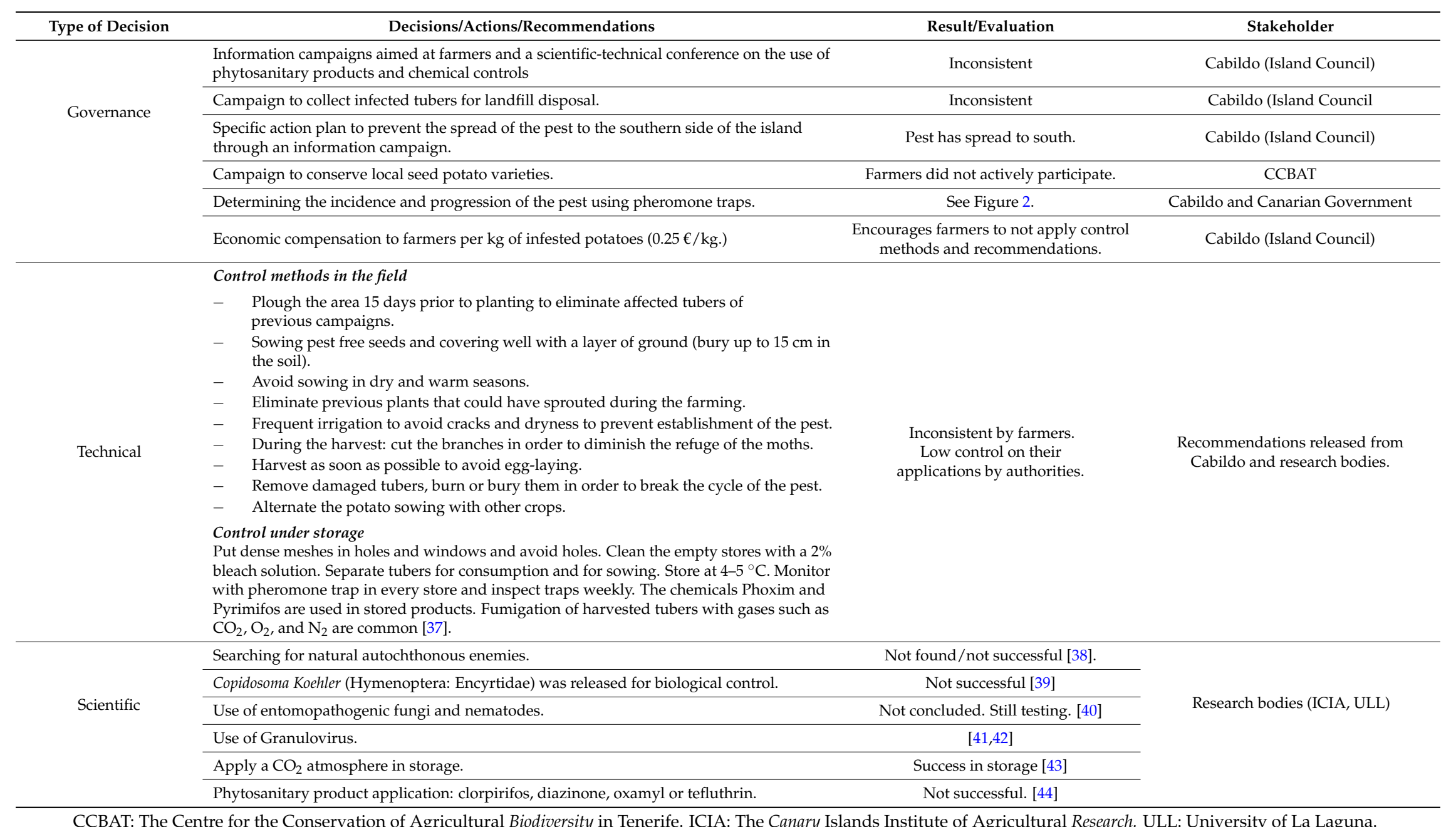


Policy decisions and recommendations did not lead to the expected results, since their application have not been regularly followed by farmers and authorities. According to scientific experts, experiments need time to achieve results, and in many cases, it has not been possible to achieve satisfactory outcomes.

According to the available statistics of Tenerife's landfill sites, during 2007, more than 500 tons of infected potatoes were collected, and during 2010, a quantity of 486 tons. These data correspond only to the tons of infested potatoes that farmers deposited in the collection containers, placed at different locations around the island by the public administration. They do not reflect the real magnitude of the problematique since they do not take into account the rest of infested potatoes that are discarded directly into the environment. This practice, unfortunately, allows the pest to reproduce freely in the open and reinfect subsequent crops, leading to much higher quantities of infested potatoes annually.

Figure 2 shows the total number of tons of infested potatoes that were collected in containers between 2004 and 2010. Before the year 2004 and after 2010, containers were not provided, hence there are no data available. Dealing with all this huge quantity of potatoes involves considerable costs for local and insular authorities, which have to provide containers, logistics and transport to the landfill, treatment at destination, alongside other services that generate expenses (see Table 1).

There have also been failings in the handling of infested potatoes. For example, by leaving them on the land or in nearby areas (ravines, etc.), new crops have been reinfected, thus perpetuating the annual cycle of pest infestation.

However, the negative effects have not only been felt in production, legislation impacts also affect business, since $T$. solanivora is classified as a quarantine organism $[45,46]$ meaning the immobilisation of the Island's potato production, banning shipment both between islands and beyond, either to the Spanish mainland or the rest of the world. This is because the larvae persist inside the potato seeds, and it is not possible to discriminate a healthy potato from an infested one during the first stages of the infestation.

The environmental aspects include the impact on traditional native potato varieties: Papas Antiguas de Canarias PDO (protected designation of origin), which have been affected by this pest. This is particularly serious as these genetic varieties are found nowhere else in the world, and the worst-case scenario could mean the disappearance of some or all of these varieties. The foreseeable consequences include: from an economic perspective, a loss of traditional farming methods that are a source of income and employment in rural areas, related to the cultivation of native potato (seedtime, irrigation, control of other plagues, conservation of the crop and soil, etc.); from an environmental perspective, the loss of agro-biodiversity through the disappearance of varieties that are unique in the world. There is also the possibility of a decline in agricultural activity with the consequent abandonment of farmland and a probable change in land use to other activities, which would mean a reclassification of the land and, therefore, a loss of its environmental function. Farmland abandonment has already happened (see Figure 2) affecting agricultural landscape due to the inactivity of the land.

Table 1 summarises the different dimension and impacts interacting in the case of the Guatemalan moth affecting the potato production in Tenerife. As has been argued, the impacts exceed agricultural or economic aspects, and affect environmental, governance and also social domains.

\section{Actions and Recommendations Taken to Date by Identified Stakeholders}

Impacts caused by the pest on different dimensions (social, economic, environmental and institutional) and a review of the decisions taken since the beginning of the problem are shown in Table 2.

\section{Method}

This case study is a clear example of a type of complex system in which the impacts are unpredictable, science has not been able to solve or contain the problem, and various opposing interests may be seen within the governance processes. 
The SIA proposed in this paper is based on an integration of various social techniques such as an extensive review of documentation and literature related to the issue, expert interviews, and a focus group centred on farmers in order to concentrate farmers' knowledge and integrate it into the analysis (see Figure 5).

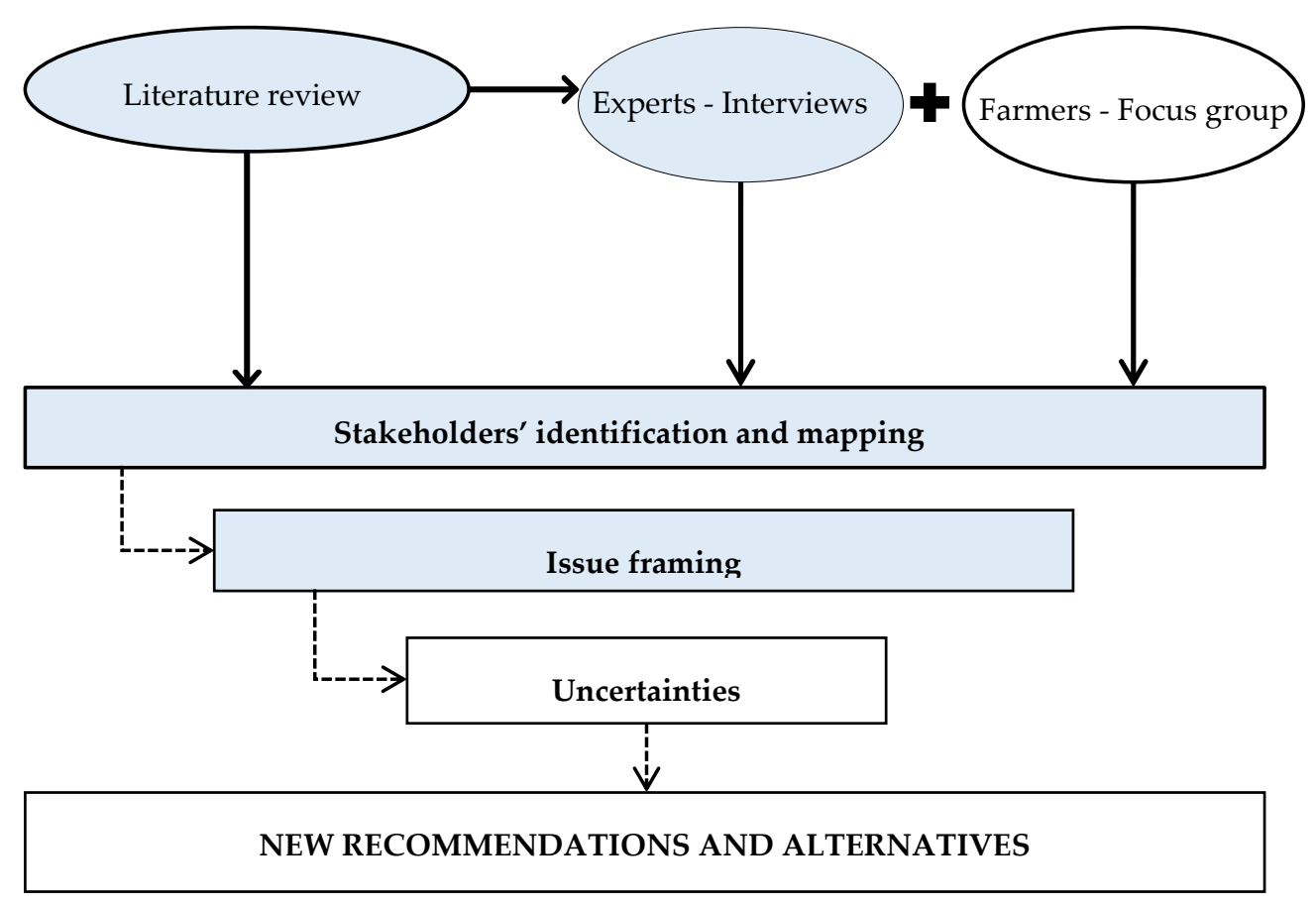

Figure 5. Socio-institutional based framework applied. In blue: Socio Institutional Assessment (SIA) Method. Note: Boxes reflect findings, circles are the applied tools.

The proposed methodology aims at tackling the problem at hand from a broad perspective, paying particular attention to the following: (a) the social context in which policies and decisions are taken; and (b) the stakeholders involved in the process, as well as their interests and interrelationships [2]. Particularly, the main objectives of this social analysis are twofold:

(1) Issue framing. In order to contextualise the problematique, covering all possible analytical variables and to analyse the social, environmental, economic and governance interrelationships caused by the pest. To this end, social research techniques, such as a literature review (press, articles, documents, legislation, etc.), and expert interviews were used.

(2) Stakeholder identification and mapping. To identify the preferences and interests that cannot be explained and forecast on the basis of a homo-economicus rationality, but are conditioned by rules, by the role of institutions, by values and habits, and interactions with other stakeholders [5]. This sub-objective is, therefore, about identifying the stakeholders, a static element of the decision-making processes, and identifying the interactions and potential conflicts between them.

Additionally, a third sub-objective emerged during the analysis process, the identification of factors that create uncertainties in the system under study. Uncertainty has been studied extensively in the literature under various categories and definitions $[47,48]$. The above two steps enabled influential elements that were hidden in the system to be detected. This allows decision-making based on better knowledge of the complexity of the problem. It is not about defining the uncertainties per se, but identifying factors that burden decision-making with uncertainty.

Applying a key informant approach, in-depth interviews were carried out with six experts from different fields of activity and knowledge related to the issue during January and May 2015. Each 
interview was carried out in a face-to-face format with duration of approximately $2 \mathrm{~h}$. The information extracted from these interviews was complemented by specific questions by e-mail.

Questions asked that were related to: (a) the relationship with other stakeholders (i.e., Are there explicit conflicts between groups? Do you perceive contradictions between stakeholders' recommendations and/or actions? Have there been collaborative management or participatory research processes previously? Do you think these processes are important? Can you explain the role of different groups and knowledge involved in the problematique: scientists, technicians, policy makers, farmers, entrepreneurs ... ) ; (b) behaviour of farmers (i.e., Do you think they follow recommendations? Do you think that the information released from scientific and technical authorities reach all the potato farmers on the island? Would farmers' knowledge and experience be relevant to decision-making processes?); (c) main impacts caused by the pest; (d) expectations for the future (i.e., Will the pest be eradicated from the island? if yes, by what means? if not, why not? Which variables will influence the spread of the pest? Are there uncontrollable variables?); (e) new recommendations to take.

Experts were selected according to the following criteria: (a) level of involvement in solving the problem; (b) experience of the problem (personal knowledge, fieldwork); (c) knowledge of the species Tecia solanivora and potato cultivation in Tenerife (measured in terms of publications and/or teaching on the subject); and (d) representativeness of a social sector (political-administrative, civil society, science and technology). The identified experts are shown in Table 3.

Table 3. Stakeholders interviewed.

\begin{tabular}{ll}
\hline \multicolumn{1}{c}{ Experts } & \multicolumn{1}{c}{ Field of Knowledge } \\
\hline A member of a local Rural Development Association & $\begin{array}{l}\text { Representative of civil society; knowledge of the } \\
\text { potato sector. }\end{array}$ \\
\hline A researcher from a regional R\&D institution (ICIA) & $\begin{array}{l}\text { High level of involvement; knowledge of T. solanivora; } \\
\text { representative of the science sector. }\end{array}$ \\
\hline A potato farmer from the north of the island & $\begin{array}{l}\text { Fieldwork; representative of the civil society; directly } \\
\text { affected. }\end{array}$ \\
\hline $\begin{array}{l}\text { A researcher from the Department of a research and } \\
\text { educational institution (ULL) }\end{array}$ & $\begin{array}{l}\text { Knowledge of the species Tecia solanivora and potato } \\
\text { cultivation in Tenerife; high level of involvement; } \\
\text { representative of the science sector. }\end{array}$ \\
\hline $\begin{array}{l}\text { A technician from the Agricultural Department of a } \\
\text { municipality (Municipality of La Victoria) }\end{array}$ & $\begin{array}{l}\text { Experience of the problem (personal knowledge, } \\
\text { fieldwork); knowledge of the species; representative } \\
\text { of the political-administrative sector. }\end{array}$ \\
\hline $\begin{array}{l}\text { A technician from the Agricultural Extension Agency } \\
\text { in the north of the island (Cabildo, Island Council) }\end{array}$ & $\begin{array}{l}\text { Experience of the problem (personal knowledge, } \\
\text { fieldwork); knowledge of potato cultivation in } \\
\text { Tenerife; representative of the political-administrative } \\
\text { and science sector. }\end{array}$ \\
\hline
\end{tabular}

ICIA: The Canary Islands Institute of Agricultural Research. ULL: University of La Laguna.

The purpose of these interviews was to create socially robust knowledge by either filling the gaps in the analysts' understanding or providing a different perspective on the issue, as well as allowing experts to reflect their take on events and offer them the opportunity to voice social actors' opinions on the problem [49].

Considering farmers as a wide and heterogeneous group, a focus group was carried out to elicit the visions and expectations that they have about the issue. The focus group was planned according to heterogeneous criteria: (a) interest in the protection of ancient varieties; (b) importers; (c) domestic farmers; (d) large producers; all of them were affected by the infestation.

The group was composed of twelve potato farmers, with ages between 35 and 84 years old, from several agricultural districts of the north of the island. Two of them are members of a Rural Association that works on an insular level; one of them is a large local producer and also imports potatoes at a regional level; two are sizeable entrepreneurs of vegetables and potatoes; four of them produce for 
local markets (municipality); and three are domestic farmers interested in conservation of ancient genetic varieties.

The research group structured the session in four main points: (a) the existence of the moth, impacts and consequences for participants; (b) the relationship between farmers and other stakeholders as scientists, council, technicians, cooperatives and rural associations (Are they listened to in decision-making? Have they participated somehow in a decision process? Do they agree with decisions taken?); (c) their expectations about the future; and (d) actions and strategies to fight against the infestation.

The research team asked questions orally to each participant, and then a debate after each question arose in a natural manner, highlighting the concerns of all participants. The whole session was recorded and the relevant information was extracted during the posterior analysis.

\section{Results}

The methodological process allows an analysis of the results in a progressive and qualitative manner, in which ultimate outputs, presented as original recommendations and actions, are structured under social, economic, environmental and institutional dimensions and contrasted with historic decisions taken by technicians and policy institutions since the beginning of the problem.

\subsection{Stakeholder Identification and Mapping}

As shown in Table 4, four groups were identified according to their geographical level. At a local level, there are potato farmers and the municipal authorities of the producer regions. At an island level, there are rural associations that work to protect and develop agricultural and rural heritage; economic stakeholders such as cooperatives and exporters. CULTESA (City, Country) is a public biotechnology company dedicated to the production of plants by in vitro multiplication techniques and provides solutions to the different production and commercial strategies of farmers. CCBAT is the Centre for the Conservation of Agricultural Biodiversity in Tenerife; the University of La Laguna (ULL) as a science actor, and the Cabildo, which is the island governmental body, with its Agricultural Extension Agencies. At a regional level, there is the Canarian Government; importers of seeds and potatoes for consumption; and the Canarian Institute for Agricultural Research (ICIA). Finally, at a national level, there is the National Institute for Agricultural Research (INIA) mainly as a research funder and the Biotechnology Institute of Navarra, which has collaborated on some research projects on the Island.

Table 4. Stakeholders and their geographical level of action.

\begin{tabular}{|c|c|}
\hline Local Level & $\begin{array}{l}\text { Municipalities } \\
\text { Farmers }\end{array}$ \\
\hline Island Level & $\begin{array}{c}\text { Cabildo (Insular Government) } \\
\text { Rural Associations } \\
\text { Cooperatives } \\
\text { Exporters } \\
\text { CULTESA } \\
\text { CCBAT } \\
\text { University of La Laguna (ULL) }\end{array}$ \\
\hline Regional Level & $\begin{array}{l}\text { The Canary Islands Government } \\
\text { Importers } \\
\text { ICIA }\end{array}$ \\
\hline National Level & $\begin{array}{c}\text { INIA } \\
\text { Biotechnology Institute of Navarra }\end{array}$ \\
\hline
\end{tabular}

CULTESA: Crops and Agricultural Technology; CCBAT: The Centre for the Conservation of Agricultural Biodiversity in Tenerife; ICIA: The Canary Islands Institute of Agricultural Research; INIA: The National Institute of Agricultural Research. 
At a national and regional level, INIA (as a part of the Ministry of Agriculture) and the Canarian Government act as regulatory actors, implementing preventive measures in order to reduce the risk of dissemination of the pest. These organizations collect information and data on the pest, but the Cabildo (Island Council) is the body that makes the main monitoring effort.

Thus, decisions are made directly by the Cabildo, based on technical and scientific results and information provided by representatives of the business and science sectors, such as some cooperatives and rural associations, ICIA, CULTESA, CCBAT, ULL, and by technicians of the Canarian Government and the Agricultural Extension Agencies.

In Figure 6, actors are positioned according to their capacity to influence decision-making, the territorial scale in which they operate and the degree to which they are affected by the pest.

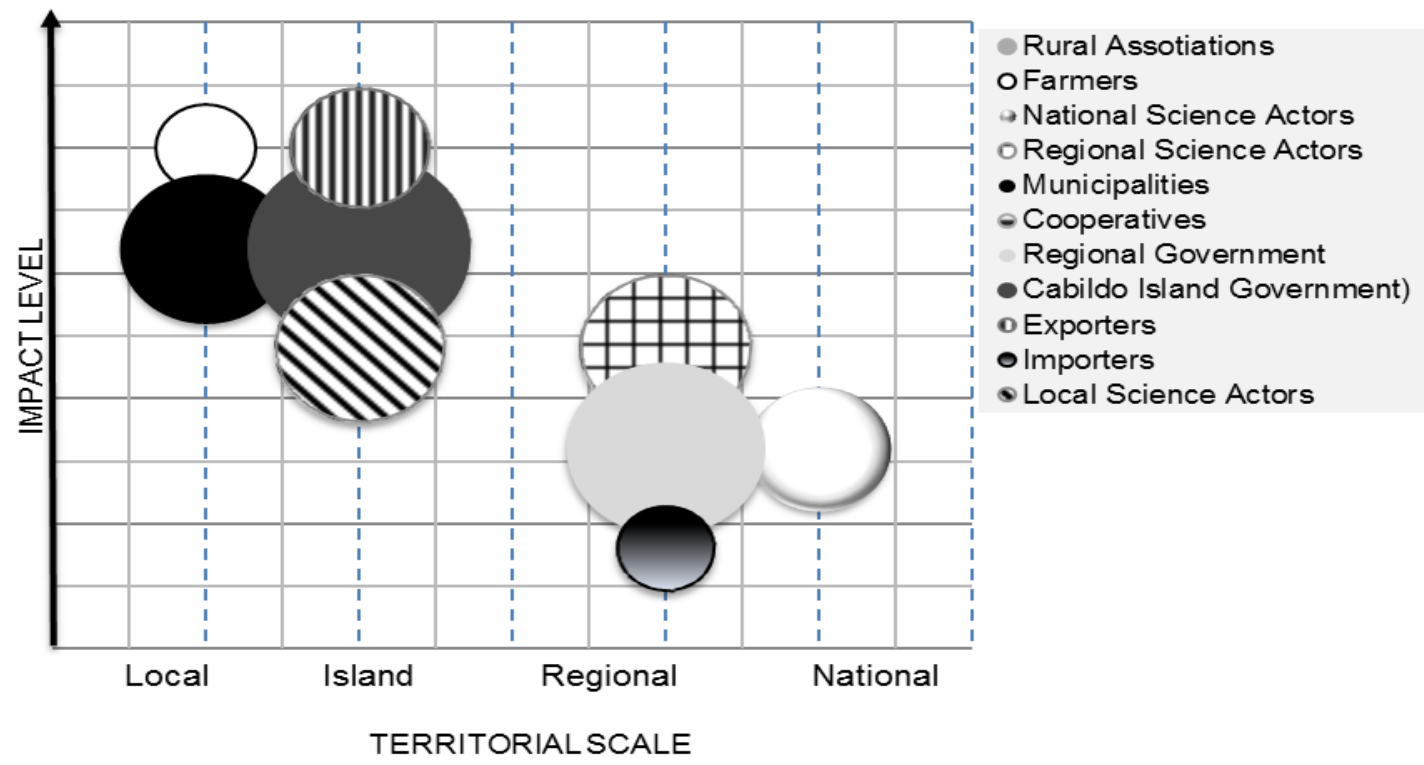

Figure 6. Stakeholder mapping in terms of impact level, territorial scale and capacity to influence the decision-making process.

At the local level, farmers are the most affected social group, the group that deals directly with the pest as they grow the crops, but they have no capacity to directly influence decision-making. Exporters are in a similar position with their activity being paralysed by the regulatory system. This group is affected in terms of opportunity costs since the production cannot be shifted to other regions. On the contrary, importers of potatoes for household consumption are unaffected by the existence of the pest. Municipalities are affected in terms of loss of employment, changes in land use and rural landscape degradation, but they do not have sufficient power to influence decisions and their economic limitations determine their range of possible actions.

At the island level, the private sector, such as cooperatives and growers organizations that are made up of farmers have suffered a huge economic impact during the years in which the pest caused great losses. As this aspect is relatively unpredictable, they have had to deal with this uncertainty every season.

Rural associations work to promote integrated rural development with the purpose of improving the quality of life of farm workers and to empower farming communities, through skills development and information initiatives. In this context, they have felt a medium level of impact on their activities because they are not conditioned by the pest, but they are in some cases concerned about this matter. In terms of their influence, these groups might be considered as pressure organizations at higher levels.

The Cabildo (Island Council) is the actor with the most responsibility for this issue and is being affected in terms of economic costs of research activities and human resources, waste management 
costs of infested potatoes, information campaign costs and the conflicts in management efforts, since it has to deal with all the actors that interact within the potato sector.

At a national and international level, there are research groups that collaborate with local technicians and scientific actors without being impacted; and the legislative power, which has a high level of influence but is not affected by the pest, since it has not spread to other territories.

\subsection{Issue Framing}

The information collected was useful to assist with the experts' interviews and farmers' focus group processes in order to build a general framing of the problematique. It helped determine the major deficiencies in order to identify the hidden uncertainties influencing the problem; and establish new alternatives and actions to take in advance by stakeholders. Four main aspects were identified in this stage:

\section{- $\quad$ Lack of participatory processes}

All the impacts discussed in Section 2 do not occur spontaneously, as said before, they are due to the interaction among different social groups with interests in the cultivation and production of potatoes on the island; thus, their behaviour and interrelationships will largely amplify the effects of the pest. In this sense, research innovations and efforts are not useful if farmers do not trust and follow instructions in an adequate manner.

"At the beginning of the problem, during the years 2002 and 2003, several efforts from technicians of Cabildo (Island Government) were carried out in order to involve farmers from affected areas into a process targeted at transferring information about the dynamic and behaviour of the new moth. These efforts consisted of periodical meetings and crop visits, but resulted in a progressive loss of interest from farmers, and finally these meetings were abandoned." ( [50])

There is no exchange of knowledge based on the experience of farmers on the ground, and their experience and knowledge is usually given very little consideration. They form a group that may be considered a mere recipient of scientific and institutional information, and this leads to "malpractice" in the field as they do not trust or have the specific or appropriate knowledge of the measures that experts consider necessary to control the pest. However, the focus group revealed that farmers have a clear and holistic vision of the problem. Trust and coordination-or the lack of-among the relevant actors interacting at all levels of the potato sector (production, commercialisation, consumption, etc.) can influence and lead to decisions with positive but also some with negative results.

- Harmful environmental practices

This disconnection is not unique to this case study, for instance, Carrillo et al. [13] found that due to the risk of high losses, lack of collaborative management, insufficient extension programs and the involvement of other important pest problems, potato growers tend to rely on the application of chemical pesticides as their only management option. In our case, researchers and technicians coincide:

(1) Researcher I "The results we have been obtaining have been disseminated in such a way that farmers, agricultural agents and cooperative managers can understand them. However, the hardest thing is to make them understand that to provide a solution, time is needed to develop and evaluate tests... Farmers seek a quick solution in the field because they do not want crop losses." [51]

(2) Researcher B "Farmers ask for rapid solutions, they do not want to lose their production and cannot wait for the results of scientific methods." [52]

(3) Technician V “Technicians try to communicate recommendations to farmers, but sometimes, low expectations from farmers on the results and the need to sell the production as best as possible can carry more weight on their decisions than to apply methods correctly." [53] 
Therefore, many farmers, when working on their land, do not follow the recommendations and measures prescribed by the authorities to prevent and/or control pests, and those that do are in a minority. This is due, on the one hand, to the lack of effective supervision by the authorities, and on the other hand, to the fact that the farmer loses motivation and interest in carrying out the measures after observing that the infestation has not been minimised, since:

"Farmers are not receiving adequate information to enable them to adopt the farm management measures proposed by the Cabildo and by other researchers. Farmers do not usually adopt these measures but in no way can they be blamed, because in most cases they are unaware of them. In addition, the lack of financial and technical resources, in many cases, makes them unworkable." ([54])

However, the information and research processes have mainly been top-down, this was the opinion of one of the agronomists, who was most directly involved in this issue:

"This knowledge is communicated in talks given by researchers to farmers and to technicians at the farmers' offices in the municipalities so that the information can be passed on. Let me tell you, there are then many 'scientists' among the farmers and they commit atrocities in the field." ([53])

In this sense, many farmers do not trust the public administration and scientists' practices and try to attack the moth with their own strategies. Some of them spray the plants with domestic use detergent; others put bleach in the irrigation water or spray bleach directly to soil.

During the focus group, experienced farmers claim that the moth might be fought through agro-ecological practices, but there are many farmers, technicians and politicians who are not aware and generally do not know about this approach and its practices.

\section{- Inconsistent application of measures by farmers}

Many farmers do not follow the recommendations regularly because there is a lack of regular communication between farmers and technicians, additionally there is not a regular control on the application of measures by authorities.

Potato' trade between farmers from different areas of the island is a tradition. Unfortunately, this means that affected potatoes might move between crops spreading the disease. The capacity of farmers to understand the scientific methods or technical language might be a limitation in order to apply these methods during the crop seasons in a correct manner.

Besides, there is inconsistency in the application of recommended control measures on the ground between growing seasons. During some seasons intensive measures are applied and in others there is a full or partial relaxation due to misperceptions about the incidence of the pest. The argument given is that the variable weather in each growing season determines how the measures are applied, i.e., in years of plentiful rainfall the spread of the pest decreases and in dry seasons it increases, but the measures are not implemented due to the perception that the pest will not be affected.

Much of the problem has, historically, had a social origin, in terms of organisation, management and coordination, and the scientific and technical measures serve as a complement to help mitigate the consequences. They do not, however, constitute a single solution and this perception of incomplete control may be seen in the negative expectations of the experts:

"I think this pest will never be eradicated in the Canary Islands, we will always have to live with it, sometimes more heavily in some years than in others, but we must accept this situation." ([53])

"The Guatemalan potato moth is the most important problem for potato sector in terms of crop destruction and economic losses, and nowadays there are no control methods capable of stopping it." ([55])

- Non coherent economic expenses 
Tons of surplus infested potatoes are treated and destroyed in landfills. This produces economic losses for the authorities, as they have to pay farmers per kilogram (the decision to establish economic compensations per $\mathrm{kg}$ of infested potatoes $(0.25 € / \mathrm{kg})$ was rejected in the year 2011), as well as the cost of transport, storage, treatment and destruction, and maintenance of the treatment plant. In addition, it was deduced from the interviews that this was the wrong decision, since appropriate control measures were not taken, as stated by researcher I:

“... On the other hand, no one should obtain financial gain from this pest (the case of payment per kilogram) and instead of paying for the infested potatoes per kilogram there should be more control and sanctions on the part of the administration." ([51])

"Transportation to the collection containers is done under lax conditions, which helps the pest propagate. A solution has been chosen which disperses the species in transit to the warehouse." ([56])

\subsection{Uncertainties}

Another crucial aspect to understand more clearly the case study and to facilitate better decisions about the moth is the elicitation of related uncertainties. As Gallopin [57] pointed out, complex systems give rise to many sources of uncertainty, some of which, such as uncertainty due to random processes or ignorance, may be reduced by introducing more data and further research. Fundamental, irreducible uncertainty may arise from non-linear processes (e.g., chaotic behaviour), in the process of self-organisation or through determined behaviour on the part of different stakeholders or agents, each with their own goals.

The uncertainties in our system are linked to factors surrounding the issue in question and correlate with further propagation and lax control. The inter- and intra-group conflicts are shown to be indeterminate, i.e., we do not know the interrelationships that occur between the different stakeholders. This situation leads to inefficient management of all aspects related to the cultivation of potatoes and therefore facilitates the territorial propagation of the moth. Uncontrollable variables such as climate change and economic crises, which involve undetermined impacts that are very difficult to predict, also influence the issues under study. The moth has spread from the area where it was discovered to the rest of the island by several means, such as weather conditions (winds, etc.), and dispersion due to human activity (transport of produce over the island; seed exchange among farmers in different parts of the island).

The continuous outward movement of people from the islands is also a potential source of propagation of this pest to other regions:

"The phytosanitary barriers and controls are not strict enough; there is a large volume of incoming and outgoing people in a tourist area like Tenerife. A simple but real example is the number of students carrying potatoes from the island to the mainland and the rest of Europe for consumption there. In many cases, these potatoes are infested, but look healthy, so much so that even the farmers themselves classify as healthy potatoes, ones that are infested." ([51])

The tons of infested potatoes, especially those that are not under the control or within the field of vision of the groups, represent an uncertainty in terms of non-availability of data and ignorance [58]. They are not managed properly and the quantity of this type of waste being discharged into the environment is not being controlled.

So the types and sources of uncertainties shown in Table 5 were found during the analysis. 
Table 5. Types and sources of uncertainties.

\begin{tabular}{cl}
\hline Type & \\
\hline Social & Conflicts between groups \\
Environmental & Loss of agro-biodiversity \\
Environmental & Climate change \\
Environmental & Local weather for forthcoming crop seasons (rainfall, drought, high or low temperatures, etc.) \\
Economic & Crisis, lack of resources \\
Geographic & Invasion of South European Regions \\
\hline
\end{tabular}

\subsection{New Recommendations and Alternatives}

Socio-Institutional analysis allows the elaboration of a main framing extracting relevant information from the literature review and from the opinions of the stakeholders involved, and this process facilitates the identification of a set of actions needed to take in advance (see Table 6). These recommendations and alternatives are intended to tackle the pest in a better manner and to prevent uncertainties such as climate change, loss of agro-biodiversity, or reduce contradictions between stakeholders. Tables 6 and 7 summarise a set of recommendations and alternatives emerged from interviews and from farmers' perceptions expressed during the focus group.

Table 6. Recommendations extracted from the analysis and proposed by different actors.

\begin{tabular}{|c|c|c|c|}
\hline Dimension & Problem to Solve & Additional Recommendations & Proposed by \\
\hline Social & $\begin{array}{l}\text { Inconsistent measures } \\
\text { application. } \\
\text { Employment. } \\
\text { Loss of traditional } \\
\text { farming knowledge. }\end{array}$ & $\begin{array}{l}\text { Wide knowledge of farmers on } \\
\text { agroecosystem. } \\
\text { Promote intergenerational } \\
\text { replacement. } \\
\text { Avoid land abandonment. }\end{array}$ & $\begin{array}{l}\text { Farmers } \\
\text { Farmers, Rural } \\
\text { Development As. } \\
\text { Farmers, Rural } \\
\text { Development As. }\end{array}$ \\
\hline Economic & $\begin{array}{l}\text { Non coherent economic } \\
\text { expenses. } \\
\text { Economic losses. } \\
\text { Production decline. }\end{array}$ & $\begin{array}{l}\text { Increase sanitary control of } \\
\text { potato imports. } \\
\text { Eliminate subsidies and } \\
\text { compensations. }\end{array}$ & $\begin{array}{l}\text { All actors } \\
\text { ICIA/Farmers }\end{array}$ \\
\hline Environmental & $\begin{array}{l}\text { Harmful environmental } \\
\text { practices. } \\
\text { Loss of } \\
\text { Agro-biodiversity. } \\
\text { Farmland abandonment } \\
\text { and Landscape } \\
\text { transformation. }\end{array}$ & $\begin{array}{l}\text { Agroecosystem practices/No } \\
\text { phytosanitary products. } \\
\text { Rotation of crops. } \\
\text { Constant field labour. } \\
\text { Climate Change adaptation } \\
\text { strategies. "The moth will do } \\
\text { that". }\end{array}$ & $\begin{array}{l}\text { Farmers/Rural } \\
\text { Development Assoc. } \\
\text { Farmers/Cabildo/ULL } \\
\text { Cabildo/Farmers/ } \\
\text { Municipality } \\
\text { ULL }\end{array}$ \\
\hline Institutional & $\begin{array}{l}\text { Lack of participatory } \\
\text { processes. } \\
\text { Conflicts and } \\
\text { disorganization. }\end{array}$ & $\begin{array}{l}\text { Maintain technical } \\
\text { recommendations (Table 4) and } \\
\text { increase control of their } \\
\text { application. } \\
\text { Promote stakeholders' } \\
\text { cooperation and communication. } \\
\text { Increase participatory research } \\
\text { between scientists and farmers. }\end{array}$ & $\begin{array}{l}\text { All actors } \\
\text { Farmers } \\
\text { Farmers }\end{array}$ \\
\hline
\end{tabular}

ICIA: The Canary Islands Institute of Agricultural Research. ULL: University of La Laguna.

Table 7. Main alternatives to eliminate the infestation.

Alternatives
(a) Adjust the seedtime in order to break the reproduction cycle of the moth.
(b) Establish a moratorium of 4 or 5 months in which the potato farming would be forbidden.
(c) Restriction of 3 years without potato farming on the whole island.

Farmers expressed concern about the pest and a lack of trust in technicians, scientists and institutions, but some of them demonstrated a holistic vision of the problematic, given that they expressed concerns on environmental, social-economic and institutional aspects. Others demonstrated 
individualism, meaning that the pest is a specific "on the field" problem of each farmer and no institutional or scientific intervention is needed. The research team asked them to turn these concerns into proposals, which led to the majority expressing their trust in agroecological practices as the best way to fight the moth, except for major entrepreneurs and importers, who were not concerned about this topic.

Three main alternatives were proposed from several actors (Table 7) to eliminate definitively the infestation on the island.

According to farmers and scientific actors, these alternatives would definitively eliminate the infestation on the island because the moths' larvae only feed on potato tubers, and without food, moths' reproduction is not possible.

It can be seen that the recommendations (Table 6) and alternatives (Table 7) are not beneficial for every actor, although they have been proposed by experts and farmers. For this reason, it is necessary to carry out an inclusive process that allows a consensus to be reached and a common strategy established.

Significantly social-economic impacts can be anticipated if alternatives are implemented. Mainly, alternatives (b) and (c) represent a shock affecting several dimensions on the production chain and food sovereignty in the island since the production value of potatoes in Santa Cruz de Tenerife represents approximately 13 million euros year. Aspects such as loss of employment related to potato production (see Table 1), imports intensification to compensate the non-availability of potatoes in the island, or household economy might be affected. Thus, a precautionary approach that includes cost-benefit and large-scale analysis is mandatory in order to prevent negative consequences.

\section{Conclusions}

Many authors [59] discuss the need to balance the stated purposes, expectations and wishes with the practical need to build new decision-making processes that include not only new structures, but also new ways of thinking, communicating and interacting. In the current case, it has been highlighted that public administrations and research bodies have based their actions solely on technical and scientific aspects and have undervalued other important factors such as the role of traditional knowledge in the use of land; the agro-ecosystem management, which could have controlled the pest in the field much better; the potato trade between different agricultural areas of the island, a well-known traditional practice; or domestic farmers who are not involved in the productive sector, but did not receive the information thus allowing the moth to reproduce. The great capacity of dispersion of this pest has an important social component, rather than ecological.

The methodology applied allows a broad qualitative contextualisation due to the identification of several dimensions of analysis, such as the social-economic and environmental impacts, the relationship among stakeholders, the decisions taken from a historic perspective, and facilitates an analysis of the problematic from different points of view and interests of the different actors involved. This allows several alternatives and actions to be identified that could complement the current decision-making processes and open new lines of research on the issue under study. Opinions and expectations are elicited to integrate different sources of knowledge and types of uncertainty into participatory processes that could change the decisions taken so far.

Every actor involved is capable of proposing several recommendations and alternatives, which have not been proposed previously in a public manner. These alternatives and recommendations are shown in Section 4.4, and their objective is to complement the actions taken so far since the beginning of the problematic. Thus, four general questions, aside from main impacts (Table 1) need to be answered:

- How to increase participatory processes.

- How to avoid harmful environmental practices.

- How to apply consistent measures during field labour.

- How to increase control over economic costs. 
These are relevant questions to help search for solutions that complement scientific and technical advances and recommendations. It is not a matter of undervaluing experimental scientific knowledge applied to the control of agricultural pests, but rather integrating it into strategies and methods that provide a holistic view of the system in which these pests thrive.

Scientists and farmers declare that by applying one of the alternatives shown in Table 6, the pest will be eliminated from the island, but making this decision will lead to conflicts and social-economic impacts. Adopting one of these alternatives implies several consequences, thus, important questions emerge: What are the economic, environmental and social costs of each alternative and for each actor? Who would take this decision, and in what manner?

Here lies complexity, in cases like this one that are characterized by "uncertain facts, values in dispute, high stakes and urgent decision-making" [60]. Decision-making processes, under these conditions, demand inclusive, transdisciplinary and participatory approaches. An exotic agricultural pest is not a simple issue; diagnosis and strategies to face it should recognise the inherent systemic and social complexities. This means that there are not only technical and environmental variables, but also social, cultural, economic, ecological and political ones that surround a pest infection, which cannot be avoided and have to be taken into account.

Acknowledgments: We would like to thank the Canarian Agency for Research, Innovation and Information Society, which provided the University of Laguna with substantial funding-co-financed by the European Social Fund $(85 \%)$ - to make the publication of this article possible. The authors would also like to thank the Icod de los Trigos-San Juan de la Rambla Rural Development Association, researchers from ICIA (Canarian Institute for Agricultural Research), the Agricultural Department of the Municipality of La Victoria de Acentejo, the Department of Plant Biology of the University of La Laguna and the Agricultural Extension Agency of La Orotava for their contributions, and personally, to the farmers who participate in the focus group.

Author Contributions: David Romero Manrique De Lara carried out the case study. Serafin Corral provided expertise in methodology and analysis of results. David Legna De La Nuez and Jesús Hernández Hernández revised the results and the coherence of the paper. The article was improved by the contributions of all of the co-authors at various stages of the analysis and writing process.

Conflicts of Interest: The authors declare no conflict of interest.

\section{References and Note}

1. Corral, S.; Legna-de la Nuez, D.; Romero-Manrique de Lara, D. Integrated assessment of biofuel production in arid lands: Jatropha cultivation on the island of Fuerteventura. Renew. Sustain. Energy Rev. 2015, 52, 41-53. [CrossRef]

2. Corral Quintana, S. Una Metodología Integrada de Exploración y Comprensión de los Procesos de Elaboración de Políticas Públicas; Univ. La Laguna: La Laguna, Spain, 2004. (In Spanish)

3. Kogan, M. Integrated pest management: Historical perspectives and contemporary developments. Annu. Rev. Entomol. 1998, 43, 243-270. [CrossRef] [PubMed]

4. Palis, F.G.; Singleton, G.; Sumalde, Z.; Hossain, M. Social and cultural dimensions of rodent pest management. Integr. Zool. 2007, 2, 174-183. [CrossRef] [PubMed]

5. Bacon, C.M.; Getz, C.; Kraus, S.; Montenegro, M.; Holland, K. The social dimensions of sustainability and change in diversified farming systems. Ecol. Soc. 2012, 17, 41. [CrossRef]

6. Subedi, M.; Hocking, T.J.; Fullen, M.A.; McCrea, A.R.; Milne, E. Lessons from Participatory Evaluation of Cropping Practices in Yunnan Province, China: Overview of the Effectiveness of Technologies and Issues Related to Technology Adoption. Sustainability 2009, 1, 628-661. [CrossRef]

7. Armah, F.A.; Yawson, D.O.; Pappoe, A.N.; Afrifa, E.K. Participation and Sustainable Management of Coastal Lagoon Ecosystems: The Case of the Fosu Lagoon in Ghana. Sustainability 2010, 2, 383-399. [CrossRef]

8. Pollet, A.; Onore, G.; Chamorro, F.; Barragán, A. Memorias: II Taller Internacional de Polilla Guatemalteca: Avances en Investigación y Manejo Integrado de la Polilla Guatemalteca de la papa Tecia Solanivora; Quito: PUCE-CBA: Quito, Ecuador, 2004. (In Spanish)

9. Carpio, C.; Dangles, O.; Dupas, S.; Léry, X.; Lopez-Ferber, M.; Orbe, K.; Paez, D.; Rebaudo, F.; Santillan, A.; Yangari, B.; et al. Development of a viral biopesticide for the control of the Guatemala potato tuber moth Tecia solanivora. J. Invertebr. Pathol. 2013, 112, 184-191. [CrossRef] [PubMed] 
10. Barragán, A.; Pollet, A.; Prado, J.; Lagnaoui, A.; Onore, G.; Aveiga, I.; Lery, X.; Zeddam, J. La polilla guatemalteca Tecia solanivora (Povolny) (Lepidoptera: Gelechiidae) en Ecuador. Diagnóstico y perspectivas de manejo bajo un método de predicción. In Memorias II Taller Internacional de Polilla Guatemalteca; Publicación Especial. 7; Centro de Biodiversidad y Ambiente, Escuela de Biología, Pontificia Universidad Católica del Ecuador: Quito, Ecuador, 2004; pp. 5-23. (In Spanish)

11. EPPO. EPPO Reporting Service. 2016. Available online: http://archives.eppo.int/EPPOReporting/2015/ Rse-1511.pdf (accessed on 20 June 2016).

12. EPPO Global Database. First Report of Tecia solanivora in Mainland Spain. Available online: https: / /gd.eppo.int/reporting/article-5149 (accessed on 20 June 2016).

13. Carrillo, D.; Torrado-Leon, E.; Peña, J.E. Tecia solanivora Povolny (Lepidoptera: Gelechiidae), an invasive pest of potatoes Solanum tuberosum L. in the Northern Andes. Potential Invasive Pests Agri. Crops 2013, 3, 126.

14. Arias, J.H.; Jaramillo, J.A.; Arevalo, E.; Rocha, M.N.R.; Muñoz, G.L. Evaluacion de la Incidencia y Severidad del Daño de la Polilla Gigante de la Papa Tecia Solanivora en el Departamento de Antioquia; Boletin Tecnico, Corporacion Instituto Colombiano Agropecuario, Ministerio de Agricultura y Desarrollo Rural: Medellin, Colombia, 1996; p. 24. (In Spanish)

15. Torres, F.; Notz, A.; Valencia, L. Ciclo de vida y otros aspectos de la biología de la polilla de la papa Tecia solanivora (Povolny) (Lepidoptera: Gelechiidae) en el Estado Táchira, Venezuela. Bol. Entomol. Venez. 1997, 12, 95-106. (In Spanish)

16. Salgado, P.; Quintana, C.; Pereira, G.; Ituarte, M.; Mateos, P. Participative multi-criteria analysis for the evaluation of water governance alternatives. A case in the Costa del Sol (Málaga). Ecol. Econom. 2009, 68, 990-1005. [CrossRef]

17. Bromley, D.W. Economic Interest and Institutions: The Conceptual Fundations of Public Policy; Basil Blackwell: Oxford, UK, 1989.

18. Schmid, A.A. Analytical Institutional Economics: Challenging Problems in the Economics of Resources for a New Environment. Am. J. Agric. Econom. 1972, 54, 893-901. [CrossRef]

19. Ostrom, E. Governing the Commons. In The Evolution of Institutions of Collective Action; Cambridge University Press: Cambridge, UK, 1990.

20. Ostrom, E. Understanding Institutional Diversity; Princeton University Press: Princeton, NJ, USA, 2005.

21. Ingram, H.M.; Mann, D.E.; Weatherford, G.D.; Cortner, H.J. Guidelines for improved institutional analysis in water resources planning. Water Resour. Res. 1984, 20, 323-334. [CrossRef]

22. Imperial, M.T. Institutional Analysis and Ecosystem-Based Management: The Institutional Analysis and Development Framework. Environ. Manag. 1999, 24, 449-465. [CrossRef]

23. Koontz, T.M. Collaboration for sustainability? A framework for analyzing government impacts in collaborative environmental management. Sustain. Science Pract. Policy 2006, 2, 15-24.

24. Barry, J.M. Mobilized Bias and Multistakeholder Protected-Area Planning: A Socio-Institutional Perspective on Collaboration. Soc. Nat. Resour. 2011, 24, 1116-1126. [CrossRef]

25. Parra, C. Sustainability and multi-level governance of territories classified as protected areas in France: The Morvan regional park case. J. Environ. Plan. Manag. 2010, 53, 491-509. [CrossRef]

26. Kikelomo Egbelakin, T.; Wilkinson, S. Sociological and behavioural impediments to earthquake hazard mitigation. Int. J. Disaster Resil. Built Environ. 2010, 1, 310-321. [CrossRef]

27. Mulleta, F.F.; Merlet, P.; Bastiaensen, J. Questioning the "Regulatory Approach" to Large-Scale Agricultural Land Transfers in Ethiopia: A Legal Pluralistic Perspective. Law Dev. Rev. 2014, 7, 401-431. [CrossRef]

28. Nowotny, Helga, Peter Scott, and Michael Gibbons; Re-Thinking Science; Knowledge and the Public in an Age of Uncertainty: Cambridge, UK, 2001.

29. Álvarez, C.E.; Gil, J. Inventario de las Papas Presentes en la isla de Tenerife y de los Nombres que en ella Reciben; Hojas divulgativas, No 5; Servicio de Agricultura, Cabildo Insular de Tenerife: Santa Cruz de Tenerife, Spain, 1996; p. 33. (In Spanish)

30. Casañas Rivero, R.; Rodríguez Rodríguez, E.M.; Díaz Romero, C. La papa en Tenerife: Historia, Importancia Económica, Taxonomía, Fisiología, Composición Química y valor Nutritivo; Arte Comunicación Visual: Santa Cruz de Tenerife, Spain, 2003. (In Spanish)

31. Ríos, D.; Ghislain, M.; Rodríguez, F.; Spooner, D.M. What is the Origin of the European potato? Evidence from Canary Island Landraces. Crop Sci. 2007, 47, 1271-1280. [CrossRef] 
32. Ríos Mesa, D. Informe "la Polilla Guatemalteca de la Papa (Tecia solanivora) en Tenerife"; Agrocabildo: Santa Cruz de Tenerife, Spain, 2012.

33. Servicio Técnico de Agricultura y Desarrollo Rural. Avisos fitosanitarios, Papa. Available online: http: / /www.agrocabildo.org/avisos_papa.asp (accessed on 20 February 2016).

34. SANINET. La Polilla Tecia solanivora ha sido Introducida en las Islas Canarias; Notas de Prensa de Sanidad Vegetal: Madrid, Spain, 2001.

35. ISTAC. Estadística Agraria de Canarias/Series Anuales de Agricultura. Municipios, islas y Provincias de Canarias. 1999-2014. Available online: http://www.gobiernodecanarias.org/istac/jaxi-istac/menu.do? uripub=urn:uuid:ef5f2e5c-e2c4-4c1d-b5ed-c20fe946ce6f (accessed on 23 June 2016). (In Spanish).

36. Gobierno de Canarias, Consejería de Agricultura, Ganadería, Pesca y Aguas. Estadística Agraria de Canarias 1985-2010. Available online: http://www.gobcan.es/agricultura/otros/estadistica/resupdf.html (accessed on 5 March 2016).

37. Perera González, S.; Trujillo García, E. Control de la Polilla Guatemalteca de la Papa. Recolección, Almacenamiento y Gestión de la Papa Bichada; Agrocabildo: Santa Cruz de Tenerife, Spain, 2014. (In Spanish)

38. Canero, C.; Ramírez, W.; Segovia, P.; Pino, H. Evaluación del Efecto de Insecticidas Sobre Larvas de Tecia solanivora; Universidad de Los Andes (Venezuela), Instituto de Investigaciones Agropecuarias: Mérida, Venezuela, 2009. (In Spanish)

39. Carnero, A.; Padilla, A.; Perera, S.; Hernández, E.; Trujillo, E. Pest status of Tecia solanivora (Povolny 1973) (Lepidoptera: Gelechiidae), Guatemalan potato moth, in the Canary Islands. IOBC/WPRS Bull. 2008, 31, 336-339.

40. Feris, M.C.; Gutierrez, C.G.; Varela, A.; Espitia, E. Evaluacion de los hongos entomopatogenos Beauveria bassiana y Metarhizium anisopliae sobre Tecia solanivora (Lepidoptera: Gelechiidae). Rev. Colombiana Entomol. 2002, 28, 179-182. (In Spanish)

41. Chaparro, M.; Espinel, C.; Cotes, A.; Villamizar, L. Fotoestabilidad y actividad insecticida de dos formulaciones de granulovirus sobre larvas de Tecia solanivora. Rev. Colombiana Entomol. 2010, 36, 25-30. (In Spanish)

42. Gómez-Bonilla, Y.; López-Ferber, M.; Caballero, P.; Léry, X.; Muñoz, D. Costa Rican soils contain highly insecticidal granulovirus strains against Phthorimaea operculella and Tecia solanivora. J. Appl. Entomol. 2012, 136, 530-538. [CrossRef]

43. Cabildo Insular de Tenerife. Evaluación de la Aplicación de Atmósfera Controlada para el Saneamiento de Tubérculos de Papas Afectadas por Polilla Guatemalteca de la Papa (Tecia solanivora); Agrocabildo: Tenerife, Spain, 2011.

44. Trujillo, G.; Perera, G. Ensayo de Evaluación de Insecticidas en el Control de la Polilla Guatemalteca de la Papa (Tecia solanivora); Cabildo de Tenerife: Tenerife, Spain, 2008. (In Spanish)

45. Order of the Ministry of Agriculture, Fisheries and Food of 12 March 1987, establishing phytosanitary standards in the Canary Islands for the import, export and transit of plants and plant products; for the entire European Union, Directive 2000/29/EC of the Council of 8 May 2000 (OJ L 169 10/7/00) on protective measures against the introduction into the Community of organisms harmful to plants or plant products and against their spread within the Community, repealing Directive 77/93/EEC of the Council of 21 December 1976 (OJ No L 26 31/01/77), which was transposed into Spanish law by Royal Decree 2071/1993 of 26 November (BOE No. 300 16/12/93).

46. Boletín Oficial de Canarias no. 169, Monday 25 August 2008, 16695. Available online: http://www. gobiernodecanarias.org/boc/2008/169/boc-2008-169-001.pdf (accessed on 23 June 2015).

47. López Cerezo, J.A.; Luján, J.L. Ciencia y Política del Riesgo; Alianza: Madrid, Spain, 2000. (In Spanish)

48. Funtowicz, S.; Ravetz, J. Post-Normal Science. Environmental Policy under Conditions of Complexity. 2000. Available online: www.jvds.nl/pns/pns.htm (accessed on 6 April 2015).

49. Corral Quintana, S. A Quality Assurance Framezork for Policy-Making: Proposing a Quality Assurance Assistant Tool (QAAT); Science for Policy, New Challenges, New Opportunities; Oxford University Press: Oxford, UK, 2009.

50. Technician, O.; Consultant, La Orotava, Spain. Personal communication, 2015.

51. Researcher, I.; ICIA, La Laguna, Spain. Personal communication, 2015.

52. Researcher, B.; ULL, La Laguna, Spain. Personal communication, 2015.

53. Technician, V.; Consultant, La Victoria, Spain. Personal communication, 2015.

54. Farmer, K.; San Juan de la Rambla, Spain. Personal communication, 2015. 
55. Technician, O.; Consultant, La Orotava, Spain. Personal communication, 2015.

56. López, J.; Farmers' Association, San Juan de la Rambla, Spain. Personal communication, 2015.

57. Gallopin, G.; Funtowicz, S.; O'connor, M.; Ravetz, J. Una ciencia para el siglo XXI: Del contrato social al núcleo científico. Int. J. Soc. Sci. 2001, 168, 219-229. (In Spanish) [CrossRef]

58. O'Riordan, T.; Jordan, A. El principio de precaución en la política ambiental contemporánea. Environ. Values 1995, 4, 191-212. (In Spanish)

59. De Marchi, B.; Ravetz, J. Participatory Approaches to Environmental Policy. Available online: http://www. clivespash.org/eve/prb10-edu.pdf (accessed on 23 June 2015).

60. Funtowicz, S.O.; and Ravetz, J.R. A New Scientific Methodology for Global Environmental Issues. In Ecological Economics: The Science and Management of Sustainability; Costanza, R., Ed.; Columbia University Press: New York, NY, USA, 1991; pp. 137-152.

(C) 2016 by the authors; licensee MDPI, Basel, Switzerland. This article is an open access article distributed under the terms and conditions of the Creative Commons Attribution (CC-BY) license (http://creativecommons.org/licenses/by/4.0/). 